\title{
Catalytic Performance for Hydrocarbon Production from Syngas on the Promoted Co-Based Hybrid Catalysts: Influence of Pt Contents
}

\author{
Suk-Hwan Kang ${ }^{1, *}$, Jae-Hong Ryu ${ }^{1}$, Jin-Ho Kim ${ }^{1}$, Hyo-Sik Kim ${ }^{1}$, Hee Chul Yang'2, \\ Dong Yong Chung ${ }^{2}$ \\ ${ }^{1}$ Institute for Advanced Engineering (IAE), 633-2 Baegam-myeon, Cheoin-gu, Yongin-si, \\ Gyeonggi, 449-863, Korea \\ ${ }^{2}$ Korea Atomic Energy Research Institute, 989-111 Daedeok-daero, Yuseong-gu,
} Daejeon, 305-353, Korea

Received: 12 $2^{\text {nd }}$ July 2016; Revised: 31st May 2017; Accepted: 1st June 2017;

Available online: 27th October 2017; Published regularly: December 2017

\begin{abstract}
Fischer-Tropsch synthesis (FTS) reaction from syngas was investigated on the Pt-promoted cobaltbased hybrid catalysts prepared by co-precipitation method in a slurry of ZSM-5 (Si/Al=25). The hybrid catalysts were compared with each other for the different content of $\mathrm{Pt}$ as a promoter and are characterized using BET, XRD, $\mathrm{H}_{2}$-TPR and $\mathrm{NH}_{3}$-TPD. Their physicochemical properties were correlated with the activity and selectivity of the catalysts. As results, all hybrid catalysts show the $\mathrm{C}_{5}-\mathrm{C}_{9}$ yield (\%) higher than that of $\mathrm{Co}_{-} \mathrm{Al}_{2} \mathrm{O}_{3} / \mathrm{ZSM}-5$ catalyst. The Pt-promoted hybrid catalysts were found to be more promising towards production of the hydrocarbons of gasoline range and over $\mathrm{C}_{10}$. Copyright (C) 2017 BCREC Group. All rights reserved
\end{abstract}

Keywords: Syngas; Fischer-Tropsch synthesis; Hybrid catalyst; ZSM-5

How to Cite: Kang, S.H., Ryu, J.H., Kim, J.H., Kim, H.S., Yang, H.C., Chung, D.Y. (2017). Catalytic Performance for Hydrocarbon Production from Syngas on the Promoted Co-Based Hybrid Catalysts; Influence of Pt Contents. Bulletin of Chemical Reaction Engineering \& Catalysis, 12 (3): 452-459 (doi:10.9767/bcrec.12.3.592.452-459)

Permalink/DOI: https://doi.org/10.9767/bcrec.12.3.592.452-459

\section{Introduction}

Fischer-Tropsch synthesis (FTS), using syngas (including $\mathrm{CO}$ and $\mathrm{H}_{2}$ ) derived from coal, natural gas, bio-gas, or other carbon-containing materials, has recently been received considerable attention as an alternative efficient method for synthesizing clean fuels and useful chemicals [1]. In general FTS, cobalt-based catalyst was operated at temperature in the

* Corresponding Author.

E-mail: shkang@iae.re.kr (Kang, S.H.)

Telp.: +82-31-330-7880 range of $210-250{ }^{\circ} \mathrm{C}$, the main products are composed of the diesel, food grade paraffin and specialty lubricants obtained after proper upgrading processes such as hydrocracking, hydrodewaxing or isomerization reaction. On the other hand, iron-based catalyst operating at temperature around $350{ }^{\circ} \mathrm{C}$ yields the premium petrochemical naphtha and $\alpha$-olefins, as the main products [2,3].

The polymerization mechanism (known as Anderson-Schulz-Flory (ASF) distribution) in FTS reaction is inherently found to show a wide-range of hydrocarbon distribution from 
methane to heavy waxy product and the extent of ASF distribution is represented by the chain growth probability. Therefore, the hydrocarbon selectivity towards gasoline range products during FTS reaction is generally known to be limited to a maximum of $48 \mathrm{~mol} \%$ [4].

To obtain branched hydrocarbons selectively, especially for high-octane gasoline production, many efforts have been carried out intensively by modifying cobalt-based catalysts. Some researchers have investigated the hybrid or composite systems consisting of cobalt component as the FTS catalyst and zeolite as the cracking catalyst by using the following representative methods; (i) cobalt-based catalyst mixed physically with zeolites [5-7], (ii) zeolite supported cobalt-based hybrid catalyst prepared by wet-impregnation method [8], (iii) membrane-coating using zeolite component on the supported $\mathrm{Co} / \mathrm{SiO}_{2}$ catalyst [9-12], and (iv) cobalt-based hybrid catalyst co-precipitated in a slurry of zeolite [13]. However, the enhancement of Co reducibility on $\mathrm{Pt}$ as a promoter has been reported for several supports (e.g. $\mathrm{SiO}_{2}$, $\mathrm{TiO}_{2}, \mathrm{ZrO}_{2}$ ) though it seems especially pronounced in the case of $\mathrm{Al}_{2} \mathrm{O}_{3}$ [14].

In the present paper, we report the catalytic activity and product distribution obtained from FTS reaction using $\mathrm{Co}-\mathrm{Al}_{2} \mathrm{O}_{3}$-xPt/ZSM-5 $(\mathrm{Si} / \mathrm{Al}=25)$ catalysts with four different Pt content to elucidate the reducibility and acidity of hybrid catalysts with or without $\mathrm{Pt}$ as promoter for the production of gasoline range $\left(\mathrm{C}_{5}-\mathrm{C}_{9}\right)$ and $\mathrm{C}_{10+}$ hydrocarbons from syngas. The objective of this work is to find out its catalytic performance during FTS reaction on hybrid catalysts with increasing Pt content.

\section{Materials and Method}

Fischer-Tropsch synthesis (FTS) reaction for the direct production of gasoline range hydrocarbons $\left(\mathrm{C}_{5}-\mathrm{C}_{9}\right)$ from syngas was investigated on cobalt-based catalysts with promoter as $\mathrm{Pt}$. The catalysts were synthesized by coprecipitation method in an aqueous solution containing $\mathrm{Co}$ and $\mathrm{Al}$ metal precursors (cobalt nitrate and aluminum nitrate with the weight ratio of $\left.\mathrm{Co} / \mathrm{Al}_{2} \mathrm{O}_{3}=20 / 100\right)$ and $\mathrm{Na}_{2} \mathrm{CO}_{3}$ solution as a precipitating agent at $70{ }^{\circ} \mathrm{C}$ in a slurry of ZSM-5 ( $\mathrm{Si} / \mathrm{Al}=25)$. The precipitate was further aged for $3 \mathrm{~h}$ at $70{ }^{\circ} \mathrm{C}$ followed by calcination at $500{ }^{\circ} \mathrm{C}$ for $5 \mathrm{~h}$. The same procedure was followed for the different contents of Pt using the nitrate precursor. Finally, the ratios of cobalt and Pt metal components to that of ZSM-5 in the hybrid catalysts were fixed at $20 / 30$ and 0.05 (or $0.1,0.3,0.5$ )/30 by weight. The hybrid catalysts are noted as $\mathrm{Co}-\mathrm{Al}_{2} \mathrm{O}_{3}$ - $\mathrm{xPt} / \mathrm{ZSM}-5$ ( $\mathrm{x}$ is $0.05,0.1,0.3$ and 0.5).

Catalytic activity test was carried out in a tubular fixed bed reactor. Prior to the reaction, the catalyst was reduced at $400{ }^{\circ} \mathrm{C}$ for $12 \mathrm{~h}$ in a flow of $8 \% \mathrm{H}_{2}$ balanced with nitrogen. After reduction, the synthesis gas $\left(\mathrm{H}_{2} / \mathrm{CO}=2\right)$ was fed into the reactor [1]. The FTS reaction was carried out subsequently under the following reaction conditions; $\mathrm{T}=240$ and $260{ }^{\circ} \mathrm{C}, \mathrm{P}=2.0$ $\mathrm{MPa}$ and $\mathrm{SV}=4,000 \mathrm{~mL} / \mathrm{g}_{\text {cat }} \mathrm{h}$. The effluent gas from the reactor was analyzed by an online gas chromatograph (Young Lin Acme 6000 GC) employing GS-GASPRO capillary column connected with flame ionized detector (FID) for the analysis of hydrocarbons and a Carboxen-1000 packed column connected with TCD for the analysis of carbon oxides, hydrogen, methane and internal standard gas of Ar.

\section{Results and Discussion}

In previous studies, we highlighted the influence of promoter on the activity of coprecipitated $\mathrm{Co}-\mathrm{Al}_{2} \mathrm{O}_{3}$-(promoter)/ZSM-5 hybrid catalysts. In the case of $\mathrm{Ru}$ and $\mathrm{Pt}$ as promoter, the reducibility of cobalt species and the density of weak acid sites were observed to be higher, thus increasing the $\mathrm{CO}$ conversion and $\mathrm{C}_{5}-\mathrm{C}_{9}$ selectivity [13].

\subsection{Textural properties and cobalt parti- cle size of hybrid catalysts}

The BET surface area, pore volume and average pore diameter are summarized in Table 1. However, surface area of the promoted catalysts slightly increased compared to that of Co/ZSM-5 catalyst. Large specific surface area and pore volume of the catalyst affects its reducibility and the catalytic performance during FTS reaction.

In order to understand the dependence of activity for the promoted Co/ZSM-5 hybrid catalysts on their physicochemical properties, all hybrid catalysts before the reaction show the characteristic reflection peak at $2 \theta=36.8^{\circ}$ due to the presence of $\mathrm{Co}_{3} \mathrm{O}_{4}$ phase, as seen in Figure 1. The particle size of $\mathrm{Co}_{3} \mathrm{O}_{4}$ is calculated by using the X-ray line broadening method with the help of Scherrer's equation. The crystallite size of $\mathrm{Co}_{3} \mathrm{O}_{4}$ for the hybrid catalysts promoted by $\mathrm{Pt}$ content $(0.05,0.1,0.3$ and 0.5$)$ is $10.8,10.6,10.4$ and $9.6 \mathrm{~nm}$, respectively. In general, the cobalt particle size of promoted $\mathrm{Co}-\mathrm{Al}_{2} \mathrm{O}_{3} / \mathrm{ZSM}-5$ catalysts is lower than $10.9 \mathrm{~nm}$ of $\mathrm{Co}-\mathrm{Al}_{2} \mathrm{O}_{3} / Z \mathrm{SM}-5$ catalyst. The smaller particle size of the easily reducible cobalt species uniformly distributed inside the 
relatively larger pores are reported to be responsible for the higher activity of promoted $\mathrm{Co}-\mathrm{Al}_{2} \mathrm{O}_{3} / \mathrm{ZSM}-5$ hybrid catalysts [2].

\subsection{Temperature-programmed analyses ( $\mathrm{H}_{2}$-TPR and $\mathrm{NH}_{3}$-TPD)}

TPR experiments were carried out to understand the reduction behavior of cobalt oxides which is important since metallic cobalt surface sites are responsible for FTS activity. The reduction profiles of calcined hybrid catalysts are shown in Figure 2, and the degree of reduction is also calculated from $\mathrm{H}_{2}$ consumption up to $300{ }^{\circ} \mathrm{C}$ in TPR runs by dividing it with total amount of $\mathrm{H}_{2}$ consumption as summarized in Table 2. TPR profiles on hybrid catalysts exhibit two distinct reduction peaks which could

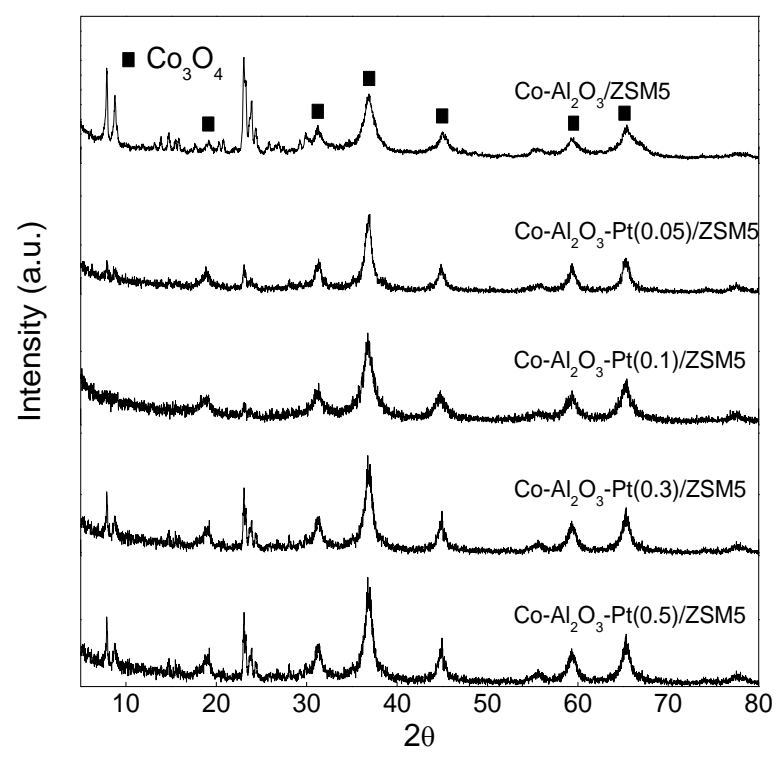

Figure 1. XRD patterns of the calcined hybrid catalysts correspond to the two-step reduction $\mathrm{Co}_{3} \mathrm{O}_{4} \rightarrow$ $\mathrm{CoO}$ and $\mathrm{CoO} \rightarrow \mathrm{Co}^{0}$ at below $422{ }^{\circ} \mathrm{C}$, and they are observed at lower temperature than that of Co- $\mathrm{Al}_{2} \mathrm{O}_{3} / \mathrm{ZSM}-5$ catalysts [15]. The first reduction peak is generally attributed to the reduction of $\mathrm{Co}_{3} \mathrm{O}_{4}$ to $\mathrm{CoO}$ and the second peak is assigned to the reduction of $\mathrm{CoO}$ to metallic cobalt. TPR profiles of three promoted Co$\mathrm{Al}_{2} \mathrm{O}_{3} /$ ZSM-5 (including Pt of 0.1, 0.3, and 0.5) catalysts also show a distinct peak at below 203-204 ${ }^{\circ} \mathrm{C}$ and an intense second peak at a maximum temperature $\left(T_{\max }\right)$ around 292-298 ${ }^{\circ} \mathrm{C}$ which could be assigned to complete reduction of cobalt oxides to metallic cobalt. The peak intensity at higher temperature region around $700{ }^{\circ} \mathrm{C}$ suggests the possible transformation of cobalt oxide to the inactive cobalt silicates on catalysts $[16,17]$.

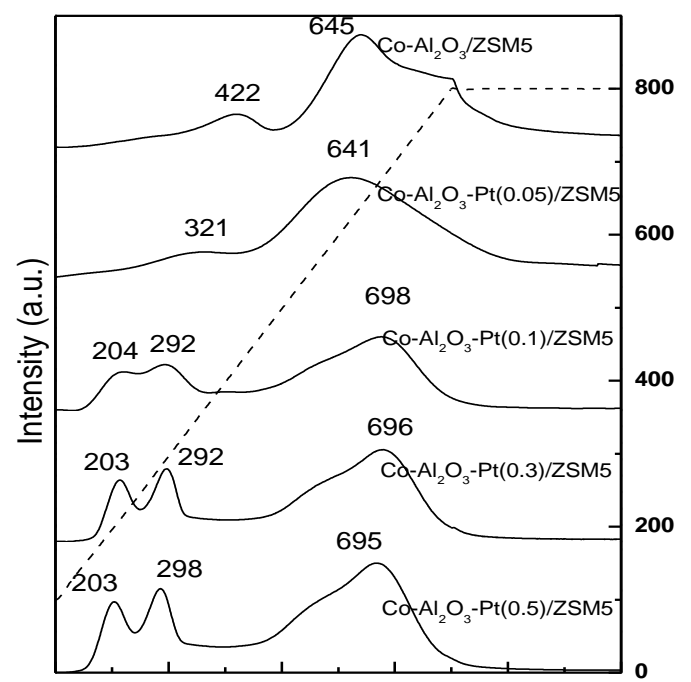

Figure 2. $\mathrm{H}_{2}$-TPR profiles of fresh Co$\mathrm{Al}_{2} \mathrm{O}_{3} / \mathrm{ZSM}-5$ and Pt promoted $\mathrm{Co}-\mathrm{Al}_{2} \mathrm{O}_{3} / \mathrm{ZSM}-5$ catalysts

Table 1. Physical properties and particle size of $\mathrm{Co}-\mathrm{Al}_{2} \mathrm{O}_{3}$-promoter/ZSM-5 catalysts

\begin{tabular}{ccccc}
\hline \multirow{2}{*}{ Notation } & \multicolumn{3}{c}{$\mathrm{N}_{2}$ adsorption method } & XRD $^{\text {a }}$ \\
\cline { 2 - 5 } & $\begin{array}{c}\text { BET surface } \\
\text { area }\left(\mathrm{m}^{2} / \mathrm{g}\right)\end{array}$ & $\begin{array}{c}\text { Pore volume } \\
\left(\mathrm{cm}^{3} / \mathrm{g}\right)\end{array}$ & $\begin{array}{c}\text { Average pore } \\
\text { diameter }(\mathrm{nm})\end{array}$ & $\begin{array}{c}\text { Particle size } \\
\text { of } \mathrm{Co}_{3} \mathrm{O}_{4}(\mathrm{~nm})\end{array}$ \\
\hline $\mathrm{Co}-\mathrm{Al}_{2} \mathrm{O}_{3} / \mathrm{ZSM}-5$ & 241.5 & 0.555 & 11.0 & 10.9 \\
$\mathrm{Co}-\mathrm{Al}_{2} \mathrm{O}_{3}-\mathrm{Pt}(0.05) / \mathrm{ZSM}-5$ & 252.5 & 0.572 & 11.2 & 10.8 \\
$\mathrm{Co}-\mathrm{Al}_{2} \mathrm{O}_{3}-\mathrm{Pt}(0.1) / \mathrm{ZSM}-5$ & 258.1 & 0.629 & 12.1 & 10.6 \\
$\mathrm{Co}_{-} \mathrm{Al}_{2} \mathrm{O}_{3}-\mathrm{Pt}(0.3) / \mathrm{ZSM}-5$ & 262.9 & 0.659 & 11.7 & 10.4 \\
$\mathrm{Co}_{-} \mathrm{Al}_{2} \mathrm{O}_{3}-\mathrm{Pt}(0.5) / \mathrm{ZSM}-5$ & 264.1 & 0.661 & 11.9 & 9.6 \\
\hline
\end{tabular}

a The particle size of $\mathrm{Co}_{3} \mathrm{O}_{4}$ is calculated by using the X-ray line broadening method with the help of Scherrer's equation 
On the other hand, $\mathrm{Co}-\mathrm{Al}_{2} \mathrm{O}_{3} / \mathrm{ZSM}-5$ and $\mathrm{Co}-$ $\mathrm{Al}_{2} \mathrm{O}_{3}-\mathrm{Pt}(0.05) / \mathrm{ZSM}-5$ showed one peak only at the low temperature around 422 and $321^{\circ} \mathrm{C}$. TPR peaks of $\mathrm{Co}-\mathrm{Al}_{2} \mathrm{O}_{3}-\mathrm{Pt}(0.5) / \mathrm{ZSM}-5$ catalyst appearing at around 204 and $292{ }^{\circ} \mathrm{C}$ could be assigned to the easily reducible cobalt crystallites to metallic state at lower temperatures. The larger surface area and smaller crystallite size of cobalt species are found to be the characteristics of $\mathrm{Co}-\mathrm{Al}_{2} \mathrm{O}_{3}-\mathrm{Pt}(0.5) / \mathrm{ZSM}-5$ catalyst, and the crystallite size of cobalt oxide and $\mathrm{T}_{\max }$ decreased with increases in $\mathrm{Pt}$ content from 321 to $298^{\circ} \mathrm{C}$. As shown in Figure 2, the Co$\mathrm{Al}_{2} \mathrm{O}_{3} / Z \mathrm{ZSM}-5$ generates a strong cobalt-ZSM-5 interaction (relatively higher reduction temperature at around $422{ }^{\circ} \mathrm{C}$ ) on acidic sites of ZSM-5 [18]. The temperature shift to lower values on $\mathrm{Co}_{-} \mathrm{Al}_{2} \mathrm{O}_{3}-\mathrm{Pt}(0.5) / \mathrm{ZSM}-5$ catalysts decreased with increasing Pt content.

The degree of reduction on hybrid catalysts was also calculated from the $\mathrm{H}_{2}$ consumption values of TPR runs. The total $\mathrm{H}_{2}$ consumption based on the weight of hybrid catalysts (denoted as total $\mathrm{H}_{2}$ consumption $/ \mathrm{g}_{\text {cat }}$ ) are calculated as the values of 2.31, 2.29, 2.35, 2.47 and $2.46 \mathrm{mmol} \mathrm{H} / 2 / \mathrm{g}_{\text {cat }}$ on $\mathrm{Co}-\mathrm{Al}_{2} \mathrm{O}_{3} / \mathrm{ZSM}-5$ catalysts with Pt of $0,0.05,0.1,0.3$, and 0.5 , respectively. Increased $\mathrm{H}_{2}$ consumption values for promoted $\mathrm{Co}_{-} \mathrm{Al}_{2} \mathrm{O}_{3} / Z \mathrm{ZSM}-5$ catalysts compared to that of $\mathrm{Co}-\mathrm{Al}_{2} \mathrm{O}_{3} / \mathrm{ZSM}-5\left(2.31 \mathrm{mmol} \mathrm{H} / \mathrm{g}_{\text {cat }}\right)$ are attributed to decrease the particle size of cobalt oxides, and total $\mathrm{H}_{2}$ consumption increased with increasing $\mathrm{Pt}$ content on Co$\mathrm{Al}_{2} \mathrm{O}_{3} / \mathrm{ZSM}-5$ catalysts. Similarly, the absolute values of $\mathrm{H}_{2}$ consumption up to $300{ }^{\circ} \mathrm{C}$ on $\mathrm{Co}$ $\mathrm{Al}_{2} \mathrm{O}_{3} / \mathrm{ZSM}-5$ catalysts at different $\mathrm{Pt}$ content were observed as $0.28,0.47,0.50$, and 0.55 $\mathrm{mmol} \mathrm{H}_{2} / \mathrm{g}_{\text {cat }}$, respectively. These observations also reveal the possible migration of cobalt species with a small size or ion exchange of cobalt species on the acidic sites of ZSM-5 surface. The shift of reduction temperature peak to lower region with the increased content of $\mathrm{Pt}$ also supports the easily reducibility of cobalt crystallites deposited on ZSM-5.
$\mathrm{NH}_{3}$-TPD experiments were carried out to investigate the concentrations of acidic sites and their strengths on promoted Co$\mathrm{Al}_{2} \mathrm{O}_{3} /$ ZSM-5 catalysts. The acidic sites on ZSM-5 could act as the active sites for the olefin cracking reaction of FTS products even at low reaction temperatures [19]. $\mathrm{NH}_{3}$-TPD patterns on hybrid catalysts are shown in Figure 3 , and two characteristic stages of $\mathrm{NH}_{3}$ desorption are observed with the peaks being assigned to peaks of I, II, and III according to the desorption temperatures such as peak I for $\mathrm{NH}_{3}$ desorption temperature below $220{ }^{\circ} \mathrm{C}$, peak II for $220-470{ }^{\circ} \mathrm{C}$ and broad peak III for above $470{ }^{\circ} \mathrm{C}$. The desorption peaks of III observed at above $470{ }^{\circ} \mathrm{C}$ are possibly attributed to water desorption from the framework of zeolite or $\mathrm{NH}_{3}$ decomposition [17], whereas the first peak of $\mathrm{I}$ at $120-220{ }^{\circ} \mathrm{C}$ could be assigned to weak acid sites or physically adsorbed am-

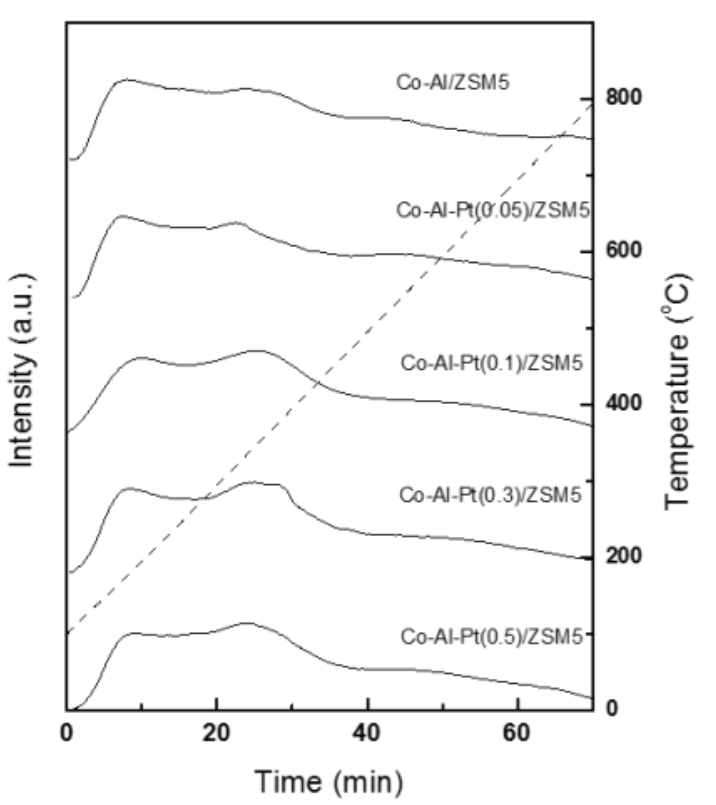

Figure 3. $\mathrm{NH}_{3}$-TPD profiles of fresh Co$\mathrm{Al}_{2} \mathrm{O}_{3} / \mathrm{ZSM}-5$ and Pt promoted $\mathrm{Co}-\mathrm{Al}_{2} \mathrm{O}_{3} / \mathrm{ZSM}-5$ catalysts

Table 2. $\mathrm{H}_{2}$ uptake of $\mathrm{Co} / \mathrm{Al}_{2} \mathrm{O}_{3}$-(promoter)/ZSM5 catalysts measured by $\mathrm{H}_{2}$-TPR

\begin{tabular}{cccc}
\hline \multirow{2}{*}{ Notation } & \multicolumn{3}{c}{$\mathrm{H}_{2}$ uptake, $\mathrm{mmol} \mathrm{H}_{2}$ /g (degree of reduction, \%) } \\
\cline { 2 - 4 } & Below $300{ }^{\circ} \mathrm{C}$ & Above $300{ }^{\circ} \mathrm{C}$ & Total uptake \\
\hline $\mathrm{Co}_{-} \mathrm{Al}_{2} \mathrm{O}_{3} /$ ZSM-5 & $0.26(11.1)$ & $2.06(88.9)$ & 2.31 \\
$\mathrm{Co}-\mathrm{Al}_{2} \mathrm{O}_{3}-\mathrm{Pt}(0.05) / Z S M-5$ & $0.28(12.23)$ & $2.17(87.77)$ & 2.29 \\
$\mathrm{Co}-\mathrm{Al}_{2} \mathrm{O}_{3}-\mathrm{Pt}(0.1) / \mathrm{ZSM}-5$ & $0.47(19.83)$ & $1.88(80.17)$ & 2.35 \\
$\mathrm{Co}-\mathrm{Al}_{2} \mathrm{O}_{3}-\mathrm{Pt}(0.3) / \mathrm{ZSM}-5$ & $0.50(20.33)$ & $1.97(79.67)$ & 2.47 \\
$\mathrm{Co}-\mathrm{Al}_{2} \mathrm{O}_{3}-\mathrm{Pt}(0.5) / \mathrm{ZSM}-5$ & $0.55(22.17)$ & $1.91(77.83)$ & 2.46 \\
\hline
\end{tabular}


monia, and the second peak of II at $220-470{ }^{\circ} \mathrm{C}$ is likely due to strong acidic sites [20]. Table 3 gives the acid site density expressed as mmol $\mathrm{NH}_{3} / \mathrm{g}_{\text {cat }}$ on $\mathrm{CoZ}$ catalysts in terms of weak and strong acidic sites. By just considering the first and second peaks (weak and strong acid sites), which could be the active sites for the olefin cracking reaction, we observe that the acid site density is found to be higher on $\mathrm{Co}-\mathrm{Al}_{2} \mathrm{O}_{3}$ $\mathrm{Pt}(0.1) / Z S M-5$ catalyst. However, the total acid site density varies in the order of $\operatorname{Pt}(0.5)>$ $\operatorname{Pt}(0.3)>\operatorname{Pt}(0,0.05$, or 0.1$)$ with the increasing the Pt content as a promoter in FTS as summarized in Table 3.

\subsection{CO conversion and product distribu- tion}

Catalytic performances of promoted Co$\mathrm{Al}_{2} \mathrm{O}_{3} / Z \mathrm{ZM}-5$ catalysts were measured at the reaction conditions of $\mathrm{P}=2.0 \mathrm{MPa}, \mathrm{SV}=3,000$ $\mathrm{ml} /$ gcat/h and $\mathrm{H}_{2} / \mathrm{CO}=2$ for over $40 \mathrm{~h}$ at a somewhat higher temperature of $240{ }^{\circ} \mathrm{C}$ to elucidate the potential ZSM-5 contribution on the olefin cracking of FTS products. CO conversion and product distribution on promoted Co$\mathrm{Al}_{2} \mathrm{O}_{3} / \mathrm{ZSM}-5$ catalysts are presented at steadystate average values of $\mathrm{CO}$ conversion and product distribution after $30 \mathrm{~h}$. In general, the catalyst having a large surface area with a large pore diameter is beneficial for obtaining a small cobalt crystallite size and facile transport of heavy hydrocarbons formed during FTS reaction. The large pores on FTS catalysts have been suggested to be linked to less coke or wax deposition [22]. The high content of weak acidic sites is also responsible for high yields to $\mathrm{C}_{5}-\mathrm{C}_{9}$ hydrocarbons, due to the possible catalytic cracking of higher molecular-weight olefins on acidic sites of zeolites [18,19]. As reported in our previous work, the physically-mixed ironbased FTS catalyst with ZSM-5 showed a high selectivity to byproducts and a low selectivity to olefinic hydrocarbons [22].

The conversion, selectivity and yield data of the hybrid catalysts are presented in Table 4 .
CO conversion proportionately increases with increasing $\mathrm{Pt}$ content and the trend correlates with the crystallite size of cobalt oxides and its reducibility as shown in Table 1 . Also, the $\mathrm{C}_{5}>$ yield with increasing Pt content increased generally. As a result, the added Pt was the role to enhance the Fischer-Tropsch synthesis by reducing the particle size of the cobalt oxides, so $\mathrm{Co}-\mathrm{Al}_{2} \mathrm{O}_{3}-\mathrm{Pt}(0.5) / Z \mathrm{ZM}-5$ catalyst showed higher $\mathrm{CO}$ conversion and yield of $\mathrm{C}_{5+}$. The $\mathrm{Co}-\mathrm{Al}_{2} \mathrm{O}_{3-}$ Pt(0.5)/ZSM-5 catalyst shows the highest CO conversion of $44.5 \%$ and the yield of $\mathrm{C}_{5}-\mathrm{C}_{9}$ (25.9\%) showed the maximum value on Co$\mathrm{Al}_{2} \mathrm{O}_{3}-\mathrm{Pt}(0.3) / Z S M-5$. This reduced selectivity towards lighter hydrocarbons could be correlated with the suppressed olefin cracking properties of heavy olefin products due to the presence of less number of acidic sites [11]. Also, the presence more number of weak acidic sites (assigned to first peak in $\mathrm{NH}_{3}$-TPD experiments) on $\mathrm{Co}-\mathrm{Al}_{2} \mathrm{O}_{3}-\mathrm{Pt}(0.3) / Z \mathrm{SM}-5$ catalyst seems to be responsible for obtaining high selectivity to $\mathrm{C}_{5}-\mathrm{C}_{9}$ hydrocarbons.

The SEM technique was used to observe the influence of $\mathrm{Pt}$ contents different on the surface morphology. The morphology of $\mathrm{Co}-\mathrm{Al}_{2} \mathrm{O}_{3}$ Pt(0.05, 0.1, and 0.3)/ZSM-5 catalysts can be showed $\mathrm{Co}-\mathrm{Al}_{2} \mathrm{O}_{3}-\mathrm{Pt}$ dispersed on ZSM-5 in Figure 4 , but that of $\mathrm{Co}-\mathrm{Al}_{2} \mathrm{O}_{3}-\mathrm{Pt}(0.5) / Z \mathrm{SM}-5$ catalyst was well dispersed enough to not be able to observe the surface of ZSM-5. From this result, although the $\mathrm{Co}-\mathrm{Al}_{2} \mathrm{O}_{3}-\mathrm{Pt}(0.5) / Z \mathrm{ZM}-5$ catalyst has the higher $\mathrm{CO}$ conversion, the selectivity of $\mathrm{C}_{5}-\mathrm{C}_{9}$ hydrocarbons was decreased by relatively low weak acidic sites.

Figure 5 shows the variation of $\mathrm{CO}$ conversion and $\mathrm{C}_{10}>$ hydrocarbon yield with increasing $\mathrm{Pt}$ content in $\mathrm{Co}-\mathrm{Al}_{2} \mathrm{O}_{3} / \mathrm{ZSM}-5$ catalyst. The increase with $\mathrm{Pt}$ content is responsible for high CO conversion, due to the small particle size of cobalt oxides. On the other hand, the yields to $\mathrm{C}_{5}-\mathrm{C}_{9}$ yield was showed the maximum value on Co- $\mathrm{Al}_{2} \mathrm{O}_{3}-\mathrm{Pt}(0.3) / Z S M-5$ catalyst. Thus, the $\mathrm{Co}-\mathrm{Al}_{2} \mathrm{O}_{3} / \mathrm{ZSM}-5$ catalyst with $\mathrm{Pt}$ improved the selectivity and yield of the $\mathrm{C}_{10}>$ hydrocarbon

Table 3. Surface acidity of $\mathrm{Co} / \mathrm{Al}_{2} \mathrm{O}_{3}$-(promoter)/ZSM5 catalysts by $\mathrm{NH}_{3}$-TPD

\begin{tabular}{cccc}
\hline \multirow{2}{*}{ Notation } & \multicolumn{3}{c}{ Acidic site $\left(\mathrm{mmol} \mathrm{NH}_{3} / \mathrm{g}\right)$} \\
\cline { 2 - 4 } & First & Second \& Third & Total \\
\hline $\mathrm{Co}_{\mathrm{Al}} \mathrm{Al}_{2} \mathrm{O}_{3} / \mathrm{ZSM}-5$ & 0.018 & 0.035 & 0.053 \\
$\mathrm{Co}-\mathrm{Al}_{2} \mathrm{O}_{3}-\mathrm{Pt}(0.05) / \mathrm{ZSM}-5$ & 0.018 & 0.036 & 0.054 \\
$\mathrm{Co}-\mathrm{Al}_{2} \mathrm{O}_{3}-\mathrm{Pt}(0.1) / \mathrm{ZSM}-5$ & 0.021 & 0.032 & 0.053 \\
$\mathrm{Co}-\mathrm{Al}_{2} \mathrm{O}_{3}-\mathrm{Pt}(0.3) / \mathrm{ZSM}-5$ & 0.019 & 0.037 & 0.056 \\
$\mathrm{Co}-\mathrm{Al}_{2} \mathrm{O}_{3}-\mathrm{Pt}(0.5) / \mathrm{ZSM}-5$ & 0.018 & 0.039 & 0.057 \\
\hline
\end{tabular}




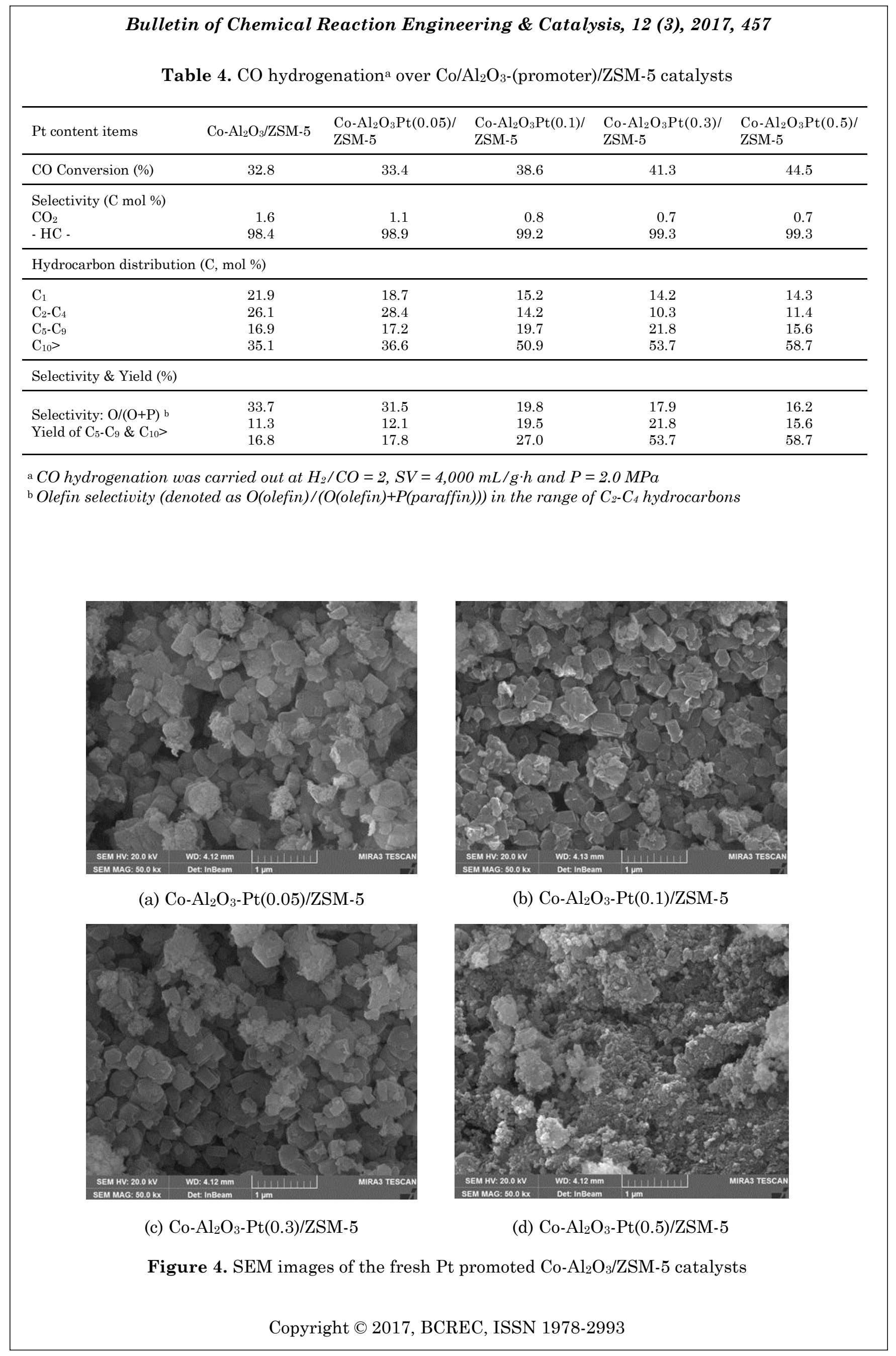




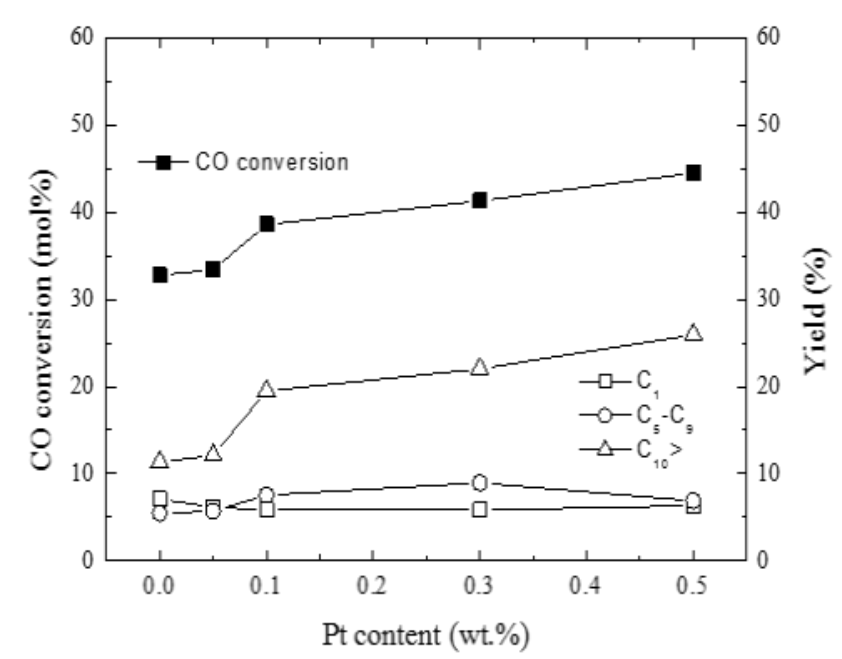

Figure 5. Correlation between the Pt content and the yield of hydrocarbons

due to higher reducibility and concentration of weak acid sites.

\section{Conclusions}

The CO conversion and hydrocarbons yield during FTS reaction of the hybrid catalysts were obtained to the different results according to the $\mathrm{Pt}$ content. The $\mathrm{Co}_{-} \mathrm{Al}_{2} \mathrm{O}_{3}-\mathrm{Pt}(0.5) / \mathrm{ZSM}-5$ hybrid catalyst offers higher $\mathrm{CO}$ conversion and $\mathrm{C}_{10+}$ yield, but the hybrid catalyst with $\mathrm{Pt}$ of $0.3 \mathrm{wt} . \%$ showed the maximum value for $\mathrm{C}_{5}$ $\mathrm{C}_{9}$ selectivity. The reducibility of cobalt particles and the concentration of weak acid sites are higher, thus consequently increasing $\mathrm{CO}$ conversion and $\mathrm{C}_{5+}$ selectivity. The presence of weak acid with large pore size and pore volume, and small cobalt particle size are mainly responsible for showing a high catalytic performance due to the high reducibility of cobalt particles.

\section{Acknowledgement}

This work was supported by the National Research Foundation of Korea (NRF) grant funded by the Korea government (MSIP) (No. NRF-2012M2A8A5025658)

\section{References}

[1] Keshav, T.R., Basu, S. (2007). Gas-to-Liquid Technologies: India's Perspective. Fuel Process. Technol., 88: 493-500.

[2] Dry, M.E. (2002). The Fischer-Tropsch Process: 1950-2000. Catal. Today, 71: 227241.
[3] Steynberg, A.P., Espinoza, R.L., Jager, B., Vosloo, A.C. (1999). High Temperature Fischer-Tropsch Synthesis in Commercial Practice. Appl. Catal. A, 186: 41-54.

[4] Martı'nez, A., Rolla'n, J., Arribas, M.A., Cerqueira, H.S., Costa, A.F., Aguiar, E.F.S. (2007). A Detailed Study of the Activity and Deactivation of Zeolites in Hybrid $\mathrm{Co} / \mathrm{SiO}_{2}$ Zeolite Fischer-Tropsch Catalysts. J. Catal., 249: 162-173.

[5] Martı'nez, A., Rolla'n, J., Arribas, M.A., Cerqueira, H.S., Costa, A.F., Aguiar, E.F.S. (2008). Catalytic Behavior of Hybrid $\mathrm{Co} / \mathrm{SiO}_{2}$ (Medium-Pore) Zeolite Catalysts during the One-Stage Conversion of Syngas to Gasoline. Appl. Catal. A, 346: 117-125.

[6] Li, Y.P., Wang, T.J., Wu, C.Z., Lv, Y., Tsubaki, N. (2008). Gasoline-Range Hydrocarbon Synthesis over $\mathrm{Co} / \mathrm{SiO}_{2} / \mathrm{HZSM}-5$ Catalyst with $\mathrm{CO}_{2}$-Containing Syngas. Energy Fuels, 22: 1897-1901.

[7] Li, Y.P., Wang, T.J., Wu, C.Z., Qin, X.X., Tsubaki, N. (2009). Effect of Ru Addition to $\mathrm{Co} / \mathrm{SiO}_{2} / \mathrm{HZSM}-5$ Catalysts on FischerTropsch Synthesis of Gasoline-Range Hydrocarbons. Catal. Commun., 10: 18681874.

[8] Liu, Z.W., Li, X., Asami, K., Fujimoto, K. (2007). Syngas to Iso-paraffins over $\mathrm{Co} / \mathrm{SiO}_{2}$ Combined with Metal/Zeolite Catalysts. Fuel Process. Technol., 88: 165-170.

[9] He, J.J., Yoneyama, Y., Xu, B.L., Nishiyama, N., Tsubaki, N. (2005). Designing a Capsule Catalyst and Its Application for Direct Synthesis of Middle Isoparaffins. Langmuir, 21: 1699-1702.

[10] Bao, J., He, J.J., Zhang, Y., Yoneyama, Y., Tsubaki, N. (2008). A Core/Shell Catalyst Produces a Spatially Confined Effect and Shape Selectivity in a Consecutive Reaction. Angewandte Chemie International, 47: 353356

[11] Yang, G.H., He, J.J., Yoneyama, Y., Tan, Y.S., Tsubaki, N. (2007). Preparation, Characterization and Reaction Performance of H-ZSM-5/Cobalt/Silica Capsule Catalysts with Different Sizes for Direct Synthesis of Isoparaffins. Appl. Catal. A, 329: 99-105.

[12] Li, X., He, J., Meng, M., Yoneyama, Y., Tsubaki, N. (2009). One-step Synthesis of H$B$ Zeolite-Enwrapped $\mathrm{Co} / \mathrm{Al}_{2} \mathrm{O}_{3}$ FischerTropsch Catalyst with High Spatial Selectivity. J. Catal., 265: 26-34.

[13] Ryu, J.H., Kang, S.H., Kim, J.H., Lee, Y.J., Jun, K.W. (2015). Fischer-Tropsch Synthesis on $\mathrm{Co}_{-} \mathrm{Al}_{2} \mathrm{O}_{3}$-(Promoter)/ZSM-5 Hybrid Catalysts for the Production of Gasoline Range Hydrocarbons. Korean J. Chem. Eng., 32: 1993-1998. 
[14] Zsoldos, Z., Garin, F., Hilaire, L., Guczi, L., (1996). Genesis of Cobalt Oxide-Induced Surface Structure in $\mathrm{PtCo}_{\mathrm{x}} \mathrm{Al}_{2} \mathrm{O}_{3}$ Catalysts. J. Mol. Catal. A, 111: 113-122.

[15] de la Osa, A.R., De Lucas, A., Romero, A., Valverde, J.L., Sánchez, P., (2011). Influence of the Catalytic Support on the Industrial Fischer-Tropsch Synthetic Diesel Production. Catal. Today, 176: 298-302.

[16] Bae, J.W., Kim, S.M., Kang, S.H., Chary, K.V.R., Lee, Y.J., Kim, H.J., Jun, K.W. (2009). Effect of Support and Cobalt Precursors on the Activity of $\mathrm{Co} / \mathrm{AlPO}_{4}$ Catalysts in FischerTropsch Synthesis. J. Mol. Catal. A, 311: 716.

[17] Łojewska, J., Kołodziej, A., Łojewski, T., Kapica, R., Tyczkowski, J., (2009). Structured Cobalt Oxide Catalyst for VOC Combustion. Part I: Catalytic and Engineering Correlations. Appl. Catal. A, 366: 206-211.

[18] Cheon, J.Y., Kang, S.H., Bae, J.W., Park, S.J., Jun, K.W., Dhar, G.M., Lee, K.Y. (2010). Effect of Active Component Contents to Catalytic Performance on Fe-Cu-K/ZSM-5 Fischer-Tropsch Catalyst. Catal. Lett., 134: 233-241.
[19] Beale, A.M., Sankar, G. (2006). Understanding the Crystallization of Nanosized Cobalt Aluminate Spinel from IonExchanged Zeolites Using Combined in situ QEXAFS/XRD. Chem. Mater., 18: 263-272.

[20] Lo'nyi, F., Valyon, J. (2001). On the Interpretation of the $\mathrm{NH}_{3}$-TPD Patterns of $\mathrm{H}$ ZSM-5 and H-mordenite. Microporous Mesoporous Mater., 47: 293-301.

[21] Kang, S.H., Bea, J.W., Sai Prasad, P.S. and Jun, K.W. (2008). Fischer-Tropsch Synthesis Using Zeolite-Supported Iron Catalysts for the Production of Light Hydrocarbons. Catal. Lett., 125: 264-270.

[22] Lee, Y.J., Park, J.Y., Jun, K.W., Bae, J.W. and Viswanadham, N. (2008). Enhanced Production of $\mathrm{C}_{2}-\mathrm{C}_{4}$ Olefins Directly from Synthesis Gas. Catal. Lett., 126: 149-154. 